OPEN ACCESS

Edited by:

Serge H. Luquet,

Paris Diderot University, France

Reviewed by:

Virginie Tolle,

French Institute of Health and Medical

Research (INSERM), France

Alexandre Benani,

Centre National de la Recherche

Scientifique (CNRS), France

${ }^{*}$ Correspondence:

Nicolas Chartrel

nicolas.chartrel@univ-rouen.fr

Specialty section:

This article was submitted to Neuroendocrine Science,

a section of the journal

Frontiers in Neuroscience

Received: 22 August 2016 Accepted: 15 November 2016 Published: 29 November 2016

Citation:

Chartrel N, Picot M, El Medhi M, Arabo A, Berrahmoune $\mathrm{H}$, Alexandre D, Maucotel J, Anouar Y and Prévost $\mathrm{G}$ (2016) The Neuropeptide 26RFa (QRFP) and lts

Role in the Regulation of Energy Homeostasis: A Mini-Review. Front. Neurosci. 10:549 doi: 10.3389/fnins.2016.00549

\section{The Neuropeptide 26RFa (QRFP) and Its Role in the Regulation of Energy Homeostasis: A Mini-Review}

\author{
Nicolas Chartrel ${ }^{1 *}$, Marie Picot ${ }^{1}$, Mouna El Medhi ${ }^{1}$, Arnaud Arabo ${ }^{2}$, Hind Berrahmoune ${ }^{1,3}$, \\ David Alexandre ${ }^{1}$, Julie Maucotel ${ }^{2}$, Youssef Anouar ${ }^{1}$ and Gaëtan Prévost ${ }^{1,3}$ \\ 1 INSERM U982, Laboratory of Neuronal and Neuroendocrine Differentiation and Communication, Institute for Research and \\ Innovation in Biomedicine, University of Rouen, Normandy University, Mont-Saint-Aignan, France, ${ }^{2}$ University of Rouen, \\ Normandy University, Mont-Saint-Aignan, France, ${ }^{3}$ Department of Endocrinology, Diabetes and Metabolic Diseases, Institute \\ for Research and Innovation in Biomedecine, University Hospital of Rouen, University of Rouen, Normandy University, Rouen, \\ France
}

This mini-review deals with the neuropeptide 26RFa (or QRFP) which is a member of the RFamide peptide family discovered simultaneously by three groups in 2003. 26RFa (or its $\mathrm{N}$-extended form 43RFa) was subsequently shown to be the endogenous ligand of the human orphan receptor GPR103. In the brain, 26RFa and GPR103mRNA are primarily expressed in hypothalamic nuclei involved in the control of feeding behavior, and at the periphery, the neuropeptide and its receptor are present in abundance in the gut and the pancreatic islets, suggesting that 26RFa is involved in the regulation of energy metabolism. Indeed, 26RFa stimulates food intake when injected centrally, and its orexigenic effect is even more pronounced in obese animals. The expression of 26RFa is up-regulated in the hypothalamus of obese animals, supporting that the 26RFa/GPR103 system may play a role in the development and/or maintenance of the obese status. Recent data indicate that 26RFa is also involved in the regulation of glucose homeostasis. 26RFa reduces glucose-induced hyperglycemia, increases insulin sensitivity and insulinemia. Furthermore, an oral ingestion of glucose strongly stimulates $26 \mathrm{RFa}$ release by the gut, indicating that 26RFa is a novel incretin. Finally, 26RFa is able to prevent pancreatic $\beta$ cell death and apoptosis. This brief overview reveals that $26 \mathrm{RFa}$ is a key neuropeptide in the regulation of energy metabolism. Further fields of research are suggested including the pathophysiological implication of the 26RFa/GPR103 system.

Keywords: RFamide peptide, G protein-coupled receptor, food intake, glucose homeostasis, obesity, diabetes

\section{DISCOVERY OF 26RFa AND ITS RECEPTOR GPR103}

26RFa also referred to as QRFP (for pyroglutamilated RFamide peptide) is a 26-amino acid peptide discovered simultaneously by three different groups in 2003 including our team (Chartrel et al., 2003; Fukusumi et al., 2003; Jiang et al., 2003). These teams have developed either a bioinformatic approach or a comparative approach using frog brains as a source of neuropeptides (Chartrel et al., 2002, 2003; Fukusumi et al., 2003; Jiang et al., 2003). 26RFa and/or its N-terminal extended form, $43 \mathrm{RFa}$, have been subsequently biochemically characterized in the human hypothalamus and the rat brain (Bruzzone et al., 2006; Takayasu et al., 2006), and molecular cloning has revealed that a 
26RFa precursor-encoding sequence is present in human (Chartrel et al., 2003; Fukusumi et al., 2003), ox (Fukusumi et al., 2003), rat (Chartrel et al., 2003; Fukusumi et al., 2003; Jiang et al., 2003), mouse (Fukusumi et al., 2003; Jiang et al., 2003), quail (Ukena et al., 2010), chicken (Ukena et al., 2010), and goldfish (Liu et al., 2009), indicating that $26 \mathrm{RFa}$ is widely distributed among vertebrates.

$26 \mathrm{RFa}$ is the cognate ligand of the human orphan receptor GPR103, also designated SP9155 or AQ27 (Chartrel et al., 2003, 2011; Jiang et al., 2003). GPR103 is a 7-transmembrane G protein-coupled receptor (GPCR) that shares significant amino acid identity (52\%) with NPFF2 (Bonini et al., 2000; Lee et al., 2001), another receptor for mammalian RFamide peptides. Binding studies and functional assays indicated that the $\mathrm{N}$ elongated form of $26 \mathrm{RFa}, 43 \mathrm{RFa}$, binds also with a high affinity to GPR103 and has the same efficacy as 26RFa to inhibit cAMP production (Fukusumi et al., 2003; Jiang et al., 2003). In contrast, GPR103 is not activated by other mammalian RFamide peptides, such as PrRP, RFRP-1 and -3 (Dockray, 2004), indicating that GPR103 selectively recognizes $26 \mathrm{RFa} / 43 \mathrm{RFa}$. Conversely, $26 \mathrm{RFa}$ displays moderate affinity and selectivity for NPFF-2 (Gouardères et al., 2007). Data mining revealed that two orthologues of human GPR103 are present in the mouse and rat genome (Kampe et al., 2006; Takayasu et al., 2006). The two GPR103 genes from rodents exhibit between 79 and 85\% homology with human GPR103 (Kampe et al., 2006; Takayasu et al., 2006). 26RFa/43RFa bind with a similar affinity the two forms of GPR103 in both mouse and rat (Kampe et al., 2006; Takayasu et al., 2006). Up to now, the occurrence of two distinct GPR103 receptors has only been reported in rodents.

\section{RFa AND CONTROL OF FEEDING BEHAVIOR}

Neuroanatomical studies have revealed a discrete localization of 26RFa-expressing neurons in various hypothalamic nuclei including the ventromedial hypothalamic nucleus (VMH), the lateral hypothalamic area (LHA) and the arcuate nucleus (Arc) (Chartrel et al., 2003; Bruzzone et al., 2007). GPR103-containing neurons are found in the same hypothalamic structures but also in other brain nuclei, such as the piriform cortex and the nucleus of the solitary tract (Bruzzone et al., 2007). All of these nuclei mentioned above are known to be involved in the control feeding behavior raising the hypothesis that $26 \mathrm{RFa}$ may be implicated in the hypothalamic regulation of food intake. This is the case as intracerebroventricular (i.c.v.) administration of $26 \mathrm{RFa}$ in mice stimulates food consumption in a dose-dependent manner, and expression of the $26 \mathrm{RFa}$ precursor is up-regulated in the hypothalamus of fasted mice (Chartrel et al., 2003; Do Rego et al., 2006; Takayasu et al., 2006). 43RFa exerts a similar effect and is even more potent than $26 \mathrm{RFa}$ in stimulating appetite (Do Rego et al., 2006; Moriya et al., 2006; Takayasu et al., 2006). In addition, chronic administration of $43 \mathrm{RFa}$ for 2 weeks results in an important increase of body weight and fat mass in mice that also exhibit a hyperphagic behavior (Moriya et al., 2006). These effects of $43 \mathrm{RFa}$ are more pronounced when mice are fed a moderately high fat diet (Moriya et al., 2006). Finally, 26RFa mRNAs are increased in genetically obese $o b / o b$ and $d b / d b$ mice (Takayasu et al., 2006), suggesting that up-regulation of $26 \mathrm{RFa}$ may play an important role in the maintenance of obesity.

$26 \mathrm{RFa}$ has also been found to stimulate food intake in rats fed a standard chow (Kampe et al., 2006; Lectez et al., 2009). Consistent with this observation, it has been recently shown that direct administration of $26 \mathrm{RFa}$ into the medial hypothalamus increases food consumption (Zagorácz et al., 2015), and that the concentrations of $26 \mathrm{RFa} / 43 \mathrm{RFa}$ in the $\mathrm{VMH}$ are significantly increased in rats fed a standard chow (Beck and Richy, 2009). It has also been found that $26 \mathrm{RFa}$ still stimulates appetite when rats are fed a high fat diet (Primeaux et al., 2008), and this phenomenon is accompanied by an up-regulation of prepro26RFa and GPR103 in the VMH and the Arc (Schreiber et al., 2016). By contrast, these authors (Primeaux et al., 2008; Schreiber et al., 2016) as well as Patel et al. (2008) failed to find any effect of $26 \mathrm{RFa}$ or $43 \mathrm{RFa}$ on food consumption when rats are fed a standard chow. Interestingly, in both mice and rats, $26 \mathrm{RFa}$ potently stimulates food intake when the animals are deprived of food for $18 \mathrm{~h}$ prior to the injection of the neuropeptide (Chartrel et al., 2003; Do Rego et al., 2006; Lectez et al., 2009) strongly suggesting that starvation potentiates the orexigenic activity of $26 \mathrm{RFa}$. To conclude, these data indicate that in both mice and rats, $26 \mathrm{RFa} / 43 \mathrm{RFa}$ strongly stimulate food consumption when the animals are fed a moderate or a high fat diet (Moriya et al., 2006; Primeaux et al., 2008), and that the expression of prepro26RFa is enhanced in the hypothalamus of animals submitted to such a fat diet (Moriya et al., 2006; Primeaux et al., 2008). These data support therefore the notion that $26 \mathrm{RFa} / 43 \mathrm{RFa}$ plays a role in the establishment and maintenance of the obese status in mammals. However, Beck and Richy (2009) have recently reported a decrease of $43 \mathrm{RFa}$ levels in the VMH of rats fed a high fat diet. Conversely, a single study has investigated the expression/production of $26 \mathrm{RFa}$ under chronic undernutrition (Galusca et al., 2012). This study has been conducted in young women suffering from anorexia nervosa in which circadian plasma $26 \mathrm{RFa}$ levels have been measured. The data reveal significant higher levels of circulating $26 \mathrm{RFa}$ in anorectic patients as compared to healthy volunteers, suggesting the occurrence of an adaptive mechanism of the organism to promote energy intake and to increase fat stores in response to chronic undernutrition (Galusca et al., 2012).

Interestingly, it has been reported that $26 \mathrm{RFa}$ promotes arousal in mice (Takayasu et al., 2006), raising the hypothesis that the orexigenic activity of the neuropeptide may be related to its wake-promoting effect, as previously suggested for the other orexigenic neuropeptide orexin. However, a recent paper reveals that, in the zebrafish, the overexpression of $26 \mathrm{RFa}$ in the hypothalamus inhibits locomotor activity and promotes sleep whereas lack of 26RFa signaling results in increased locomotor activity and decreased sleep during the day (Chen et al., 2016).

One neuronal pathway by which $26 \mathrm{RFa} / 43 \mathrm{RFa}$ exerts its orexigenic activity in the hypothalamus has been elucidated. The investigation has focused on the neuropeptide $\mathrm{Y}$ (NPY)/proopiomelanocortin (POMC) system of the Arc as a high expression of the $26 \mathrm{RFa}$ receptor is found in this nucleus 
(Sakurai et al., 1998; Fukusumi et al., 2003; Takayasu et al., 2006; Bruzzone et al., 2007). i.c.v. administration of 26RFa induces an increase in the expression and release of NPY in the Arc and, simultaneously, a decrease in POMC expression and $\alpha-\mathrm{MSH}$ release (an anorexigenic POMC-derived peptide) which is associated with an increase in food consumption (Lectez et al., 2009). In addition, in this study, Lectez et al. (2009) show that the effects of 26RFa on the activity of POMC neurons is indirect as these neurons do not express the GPR103 transcript. Specific antagonists of the Y1 and Y5 NPY receptors (which are expressed by POMC neurons) totally abolish the inhibitory effect of 26RFa on POMC expression and $\alpha-\mathrm{MSH}$ release, as well as $26 \mathrm{RFa}$-induced food intake, indicating that $26 \mathrm{RFa}$ increases consumption by stimulating the release of NPY which in turn inhibits the activity of POMC neurons via the activation of the Y1 and Y5 receptors (Lectez et al., 2009, Figure 1). A possible involvement of the orexin system in the orexigenic hypothalamic effect of $26 \mathrm{RFa}$ has also been examined because the orexin system shows important similarity with the 26RFa/GPR103 system. As a matter of fact, orexins stimulate food intake and orexin-expressing neurons are localized in the LHA (Sakurai et al., 1998), like 26RFa. The orexin neurons innervate the NPY neurons of the Arc (Ciriello et al., 2003) that express the OX-R1 receptor (Bäckberg et al., 2002). Orexin-A stimulates the activity of NPY neurons (López et al., 2002) and the orexigenic activity of the neuropeptide is abolished when the animals have previously received Y1 and Y5 NPY receptor antagonists (Dube et al., 2000; Yamanaka et al., 2000). Finally, it has been recently demonstrated that orexin receptors and GPR103 can form functional heterodimers to exert their effects through activation of ERK $1 / 2$ (Davies et al., 2015). However, the fact that $26 \mathrm{RFa}$ still stimulates appetite in orexin invalidated mice (Takayasu et al., 2006) indicates that the orexin system is not recruited during 26RFa-induced food intake. Alternatively, it is not known whether the OX receptor needs to dimerise with GPR103 to initiate orexin-induced food intake or whether orexin and 26RFa may act synergically via heterodimerization of their receptors to potentiate their orexigenic activities. This interesting hypothesis deserves further investigation.

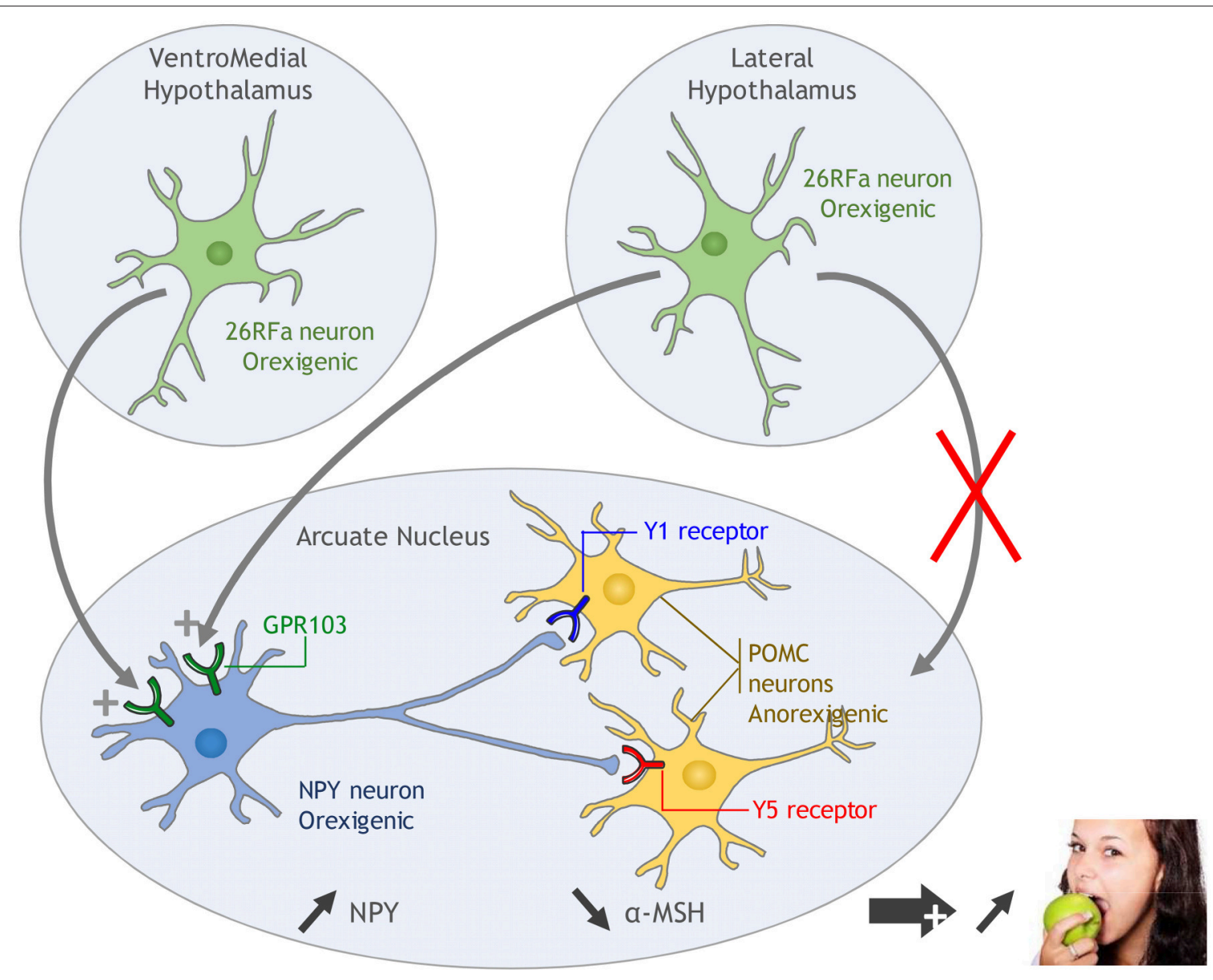

FIGURE 1 | Proposed mechanism of action of 26RFa in the hypothalamic control of food intake. 26RFa, produced by neurons of the ventromedial hypothalamic nucleus (VMH) and the lateral hypothalamic area (LHA), stimulates the activity of NPY neurons of the arcuate nucleus (Arc) via activation of GPR103. Subsequent NPY release in the Arc inhibits the activity of proopiomelanocortin (POMC) neurons via activation of the Y1 and Y5 receptors, leading to a stimulation of appetite. 
In addition to its central action, accumulating data indicate that $26 \mathrm{RFa}$ can also regulate energy homeostasis at the periphery. It has notably been shown that, in the adipocyte cells 3T3-L1, $26 \mathrm{RFa}$, and $43 \mathrm{RFa}$ stimulate triglyceride accumulation and fatty acid uptake, and increase the expression of genes involved in lipid uptake (Mulumba et al., 2010). Concurrently, the expression of GPR103 is enhanced in the adipose tissue of a mouse model of diet-induced obesity whereas that of prepro26RFa is decreased, and the neuropeptide inhibits lipolysis in adipocytes of these animals (Mulumba et al., 2010, 2015). It thus appears that 26RFa plays a crucial role in the central and peripheral regulation of body weight and energy homeostasis, and may be involved in the development and maintenance of obesity in vertebrates.

\section{RFa AND CONTROL OF GLUCOSE HOMEOSTASIS}

Type 2 diabetes, which is a frequent consequence of obesity, is characterized by chronic hyperglycemia induced by impaired insulin secretion due to decreased $\beta$ cell mass and function, and increased insulin resistance (Butler et al., 2003; Kahn et al., 2014). Recent studies suggest a peripheral role of hypothalamic neuropeptides controlling feeding behavior in the regulation of glucose homeostasis, leading to the new concept that hypothalamic neuropeptides may serve as a link between energy and glucose homeostasis, and identifying them therefore as potential therapeutic targets for the treatment of diabetes and obesity (Greenwood et al., 2011). With regard to these observations a potential role of $26 \mathrm{RFa} / 43 \mathrm{RFa}$ in the regulation of glucose homeostasis has been examined. A primary study in 2007 has investigated the effect of $26 \mathrm{RFa}$ on insulin and glucagon secretion by rat perfused pancreas (Egido et al., 2007). This study reports that $26 \mathrm{RFa}$ reduces glucose, arginine and exendin-4 (a GLP-1 agonist)-induced insulin release without affecting glucagon secretion (Egido et al., 2007). In addition, these authors show that the inhibitory effect of $26 \mathrm{RFa}$ on exendin-4-induced insulin release is not observed in pancreas from pertussis toxin-treated rats suggesting the involvement of a pertussis toxin-sensitive $G_{i}$ protein negatively coupled to the adenylyl cyclase system (Egido et al., 2007). Recently, the role and mechanism of action of $26 \mathrm{RFa} / 43 \mathrm{RFa}$ in the regulation of glucose metabolism has been studied more thoroughly (Granata et al., 2014; Prévost et al., 2015). The two studies show that $26 \mathrm{RFa} / 43 \mathrm{RFa}$ and GPR103 are expressed by the pancreatic islets as well as by the rodent insulin-secreting cell lines INS-1E and MIN6. Granata et al. (2014) report that 26RFa and 43RFa prevent cell death and apoptosis induced by serum starvation, cytokines and glucolipotoxicity in INS-1E $\beta$ cells and in isolated human pancreatic islets. In addition, these authors indicate that $43 \mathrm{RFa}$ promotes, whereas $26 \mathrm{RFa}$ inhibits, glucose - and exendin4-induced insulin secretion through $\mathrm{G} \alpha_{\mathrm{s}}$ and $\mathrm{G} \alpha_{\mathrm{i} / \mathrm{o}}$ proteins, respectively (Granata et al., 2014). They also show that inhibition of GPR103 expression by small interfering RNA in INS-1E $\beta$ cells totally blocks the insulinotropic effect of $43 \mathrm{RFa}$ but not the insulinostatic action of $26 \mathrm{RFa}$, suggesting that the insulinotropic effect of $43 \mathrm{RFa}$ is mediated via activation of GPR103 whereas, conversely, the insulinostatic effect of $26 \mathrm{RFa}$ is mediated via another unknown receptor (Granata et al., 2014). Finally, the same study reveals that $43 \mathrm{RFa}$ promotes glucose uptake by $\beta$ cells whereas 26RFa does not (Granata et al., 2014).

Our team has also investigated the role and mechanism of action of 26RFa in the regulation of glucose homeostasis (Prévost et al., 2015). Clinical studies performed in human revealed a positive correlation between plasma $26 \mathrm{RFa}$ and plasma insulin in obese, type 2 diabetic patients and healthy volunteers. In addition, measurement of plasma $26 \mathrm{RFa}$ during an oral glucose tolerance test shows an increase in the circulating levels of the neuropeptide during the test, indicating a link between the $26 \mathrm{RFa}$ system and glucose homeostasis (Prévost et al., 2015). Finally, immunohistochemical experiments describe the presence, in abundance, of $26 \mathrm{RFa}$ in the gut, from the stomach to the colon, suggesting that the gut is the primary source of circulating $26 \mathrm{RF}$ a that can be released under an oral glucose load. In mice, it was found that i.p. administration of $26 \mathrm{RFa}$ does not alter basal glycemia. In contrast, the neuropeptide strongly attenuates glucose-induced hyperglycemia during a glucose tolerance test, indicating that the neuropeptide exerts an antihyperglycemic effect rather than a hypoglycemic effect. In addition, it is reported that $26 \mathrm{RFa}$ enhances insulin sensitivity and increases insulin

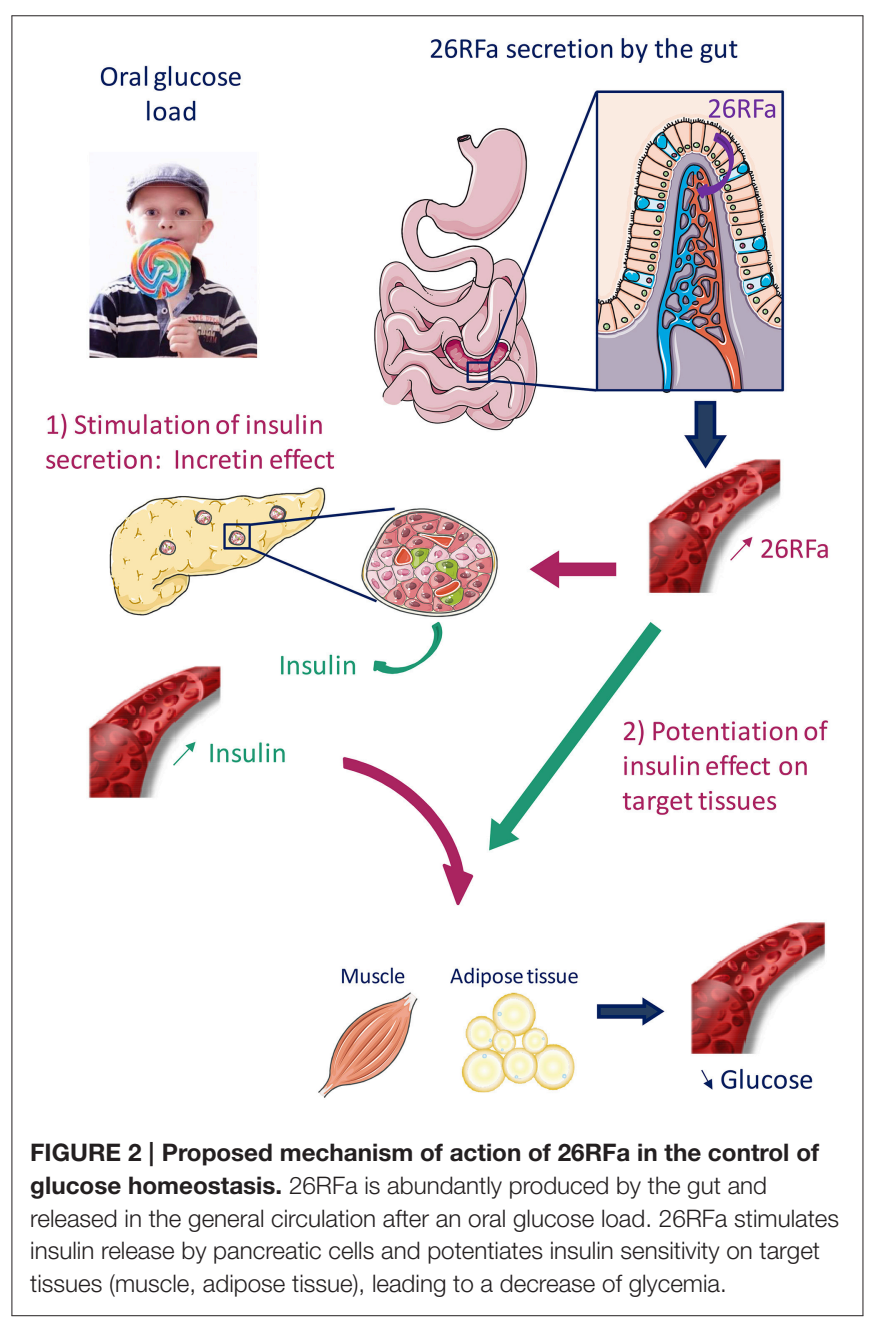


production, suggesting that the two mechanisms contribute to the antihyperglycemic effect of 26RFa. 26RFa-induced insulin production is due to a direct action of the neuropeptide on pancreatic $\beta$ cells as 26RFa stimulates insulin release by the MIN6 cells that express GPR103, and as invalidation of GPR103 in these cells totally abolishes 26RFa-induced insulin secretion (Prévost et al., 2015). These observations are partially in agreement with those of Granata et al. (2014) reporting that $43 \mathrm{RFa}$ stimulates insulin secretion by human pancreatic islets and INS-1E $\beta$ cells by activating GPR103. However, the same authors found that 26RFa exerts an opposite effect to that of $43 \mathrm{RFa}$, and that the inhibiting effect of $26 \mathrm{RFa}$ on insulin secretion is not mediated by GPR103. They thus suggest that NPFF2, another receptor that 26RFa can bind to but with a much lower affinity than to GPR103 (Moriya et al., 2006), may be involved in the insulinostatic activity of 26RFa. In our study (Prévost et al., 2015), we show that MIN6 cells do not express NPFF2 that might explain the discrepancy between the two studies.

$26 \mathrm{RFa}$ has also been found to increase insulin sensitivity and GPR103 is co-expressed with the insulin receptor and the glucose transporter, GLUT-4, in the muscle, liver and adipose tissue (Prévost et al., 2015). In addition, a recent study indicates that 26RFa enhances insulin's effects on glucose uptake in rat skeletal muscle cells (Allerton and Primeaux, 2015). Altogether, these observations strongly suggest a direct action of the neuropeptide on insulin target tissues. Finally, it has been observed that an oral ingestion of glucose induces an increase in plasma 26RFa levels $30 \mathrm{~min}$ after the glucose load, whereas this phenomenon is not observed when glucose is administrated i.v., indicating therefore that elevation of $26 \mathrm{RFa}$ in the blood is due to a massive release of the neuropeptide by the gut (Prévost et al., 2015). In conclusion, these studies promote evidence for an important role of $26 \mathrm{RFa}$, acting as an incretin, in the regulation of glucose homeostasis (Figure 2). Interestingly, a genome wide identification of new genes causing type 1 diabetes with autoimmune thyroiditis has revealed a strong association of the GPR103 gene with this pathology (Tomer et al., 2015), supporting the involvement of the $26 \mathrm{RFa} / \mathrm{GPR} 103$ system in the regulation of glucose metabolism.

\section{REFERENCES}

Allerton, T. D., and Primeaux, S. D. (2015). QRFP-26 enhances insulin's effects on glucose uptake in rat skeletal muscle cells. Peptides 69, 77-79. doi: 10.1016/j. peptides.2015.04.006

Bäckberg, M., Hervieu, G., Wilson, S., and Meister, B. (2002). Orexin receptor1 (OX-R1) immunoreactivity in chemically identified neurons of the hypothalamus: focus on orexin targets involved in control of food and water intake. Eur. J. Neurosci. 15, 315-328. doi: 10.1046/j.0953-816x.2001.01859.x

Beck, B., and Richy, S. (2009). Suppression of QRFP 43 in the hypothalamic ventromedial nucleus of Long-Evans rats fed a high-fat diet. Biochem. Biophys. Res. Commun. 383, 78-82. doi: 10.1016/j.bbrc.2009.03.132

Bonini, J. A., Jones, K. A., Adham, N., Forray, C., Artymyshyn, R., Durkin, M. M., et al. (2000). Identification and characterization of two G protein-coupled receptors for neuropeptide FF. J. Biol. Chem. 275, 39324-39331. doi: 10.1074/ jbc.M004385200

Bruzzone, F., Lectez, B., Alexandre, D., Jégou, S., Mounien, L., Tollemer, H., et al. (2007). Distribution of 26RFa binding sites and GPR103 mRNA in the central nervous system of the rat. J. Comp. Neurol. 503, 573-591. doi: 10.1002/cne. 21400

Bruzzone, F., Lectez, B., Tollemer, H., Leprince, J., Dujardin, C., Rachidi, W., et al. (2006). Anatomical distribution and biochemical characterization of the

\section{CONCLUSION}

Accumulating data obtained during the last decade reveal that the $26 \mathrm{RFa} / \mathrm{GPR} 103$ system plays an important role in the regulation of food intake and glucose homeostasis. Obesity associated with type 2 diabetes is a major world-wide problem of public health as $11 \%$ of the world population is obese (Organisation Mondiale de la Santé, 2016) and 400 millions people are affected by type 2 diabetes in the world (Kahn et al., 2014). One main axis for further research would be to investigate whether dysfunction of the 26RFa/GPR103 system is associated with diabetes/obesity that could serve as a basis to develop 26RFa analogs to treat the pathology. Supporting this idea, it can be reminded that, during the last decade, the therapeutic arsenal to treat type 2 diabetes has been enlarged with the occurrence of novel classes of drugs, such as GLP-1 agonists and inhibitors of DPPIV.

Besides, an increasing body of evidence supports the existence in the hypothalamus of a glucoregulatory system that acts coordinately with pancreatic islets to regulate blood glucose levels, via both insulin-dependent and insulin-independent mechanisms, that would be responsible of $50 \%$ of glucose homeostasis. Considering this latter observation, it would be important to investigate whether the hypothalamic neuronal populations expressing $26 \mathrm{RFa}$ are involved in the central regulation of glucose homeostasis.

\section{AUTHOR CONTRIBUTIONS}

All of the authors have contributed to the design, writing and correction of the present mini-review.

\section{FUNDING}

The work supported by the "Institut National de la Santé et de la Recherche Médicale" (INSERM U982) et the "Fondation pour la Recherche Médicale."

novel RFamide peptide $26 \mathrm{RFa}$ in the human hypothalamus and spinal cord. J. Neurochem. 99, 616-627. doi: 10.1111/j.1471-4159.2006.04090.x

Butler, A. E., Janson, J., Bonner-Weir, S., Ritzel, R., Rizza, R. A., and Butler, P. C. (2003). $\beta$-cell deficit and increased $\beta$-cell apoptosis in humans with type 2 diabetes. Diabetes 52, 102-110. doi: 10.2337/diabetes.52.1.102

Chartrel, N., Alonzeau, J., Alexandre, D., Jeandel, L., Alvear-Perez, R., Leprince, J., et al. (2011). The RFamide neuropeptide 26RFa and its role in the control of neuroendocrine functions. Front. Neuroendocrinol. 32, 387-397. doi: 10.1016/ j.yfrne.2011.04.001

Chartrel, N., Dujardin, C., Anouar, Y., Leprince, J., Decker, A., Clerens, S., et al. (2003). Identification of 26RFa, a hypothalamic neuropeptide of the RFamide peptide family with orexigenic activity. Proc. Natl. Acad. Sci. U.S.A. 100, 15247-15252. doi: 10.1073/pnas.2434676100

Chartrel, N., Dujardin, C., Leprince, J., Desrues, L., Tonon, M. C., Cellier, E., et al. (2002). Isolation, characterization and distribution of a novel neuropeptide, Rana RFamide (R-RFa), in the brain of the European green frog Rana esculenta. J. Comp. Neurol. 448, 111-127. doi: 10.1002/cne.10253

Chen, A., Chiu, C. N., Mosser, E. A., Kahn, S., Spence, R., and Prober, D. A. (2016). QRFP and its receptors regulate locomotor activity and sleep in zebrafish. J. Neurosci. 36, 1823-1840. doi: 10.1523/JNEUROSCI.2579-15.2016

Ciriello, J., McMurray, J. C., Babic, T., and de Oliveira, C. V. (2003). Collateral axonal projections from hypothalamic hypocretin neurons to cardiovascular 
sites in nucleus ambiguus and nucleus tractus solitarius. Brain Res. 991, 133-141. doi: 10.1016/j.brainres.2003.08.016

Davies, J., Chen, J., Pink, R., Carter, D., Saunders, N., Sotiriadis, G., et al. (2015). Orexin receptors exert a neuroprotective effect in alzheimer's desease (AD) via heterodimerization with GPR103. Sci. Rep. 5:12584. doi: 10.1038/srep12584

Dockray, G. J. (2004). The expanding family of -RFamide peptides and their effects on feeding behavior. Exp. Physiol. 89, 229-235. doi: 10.1113/expphysiol.2004. 027169

Do Rego, J. C., Leprince, J., Chartrel, N., Vaudry, H., and Costentin, J. (2006). Behavioral effects of 26RFamide and related peptides. Peptides 27, 2715-2721. doi: 10.1016/j.peptides.2006.04.017

Dube, M. G., Horvath, T. L., and Kalra, P. S. (2000). Evidence of NPY Y5 receptor involvement in food intake elicited by orexin A in sated rats. Peptides 21, 1557-1560. doi: 10.1016/S0196-9781(00)00311-9

Egido, E. M., Hernández, R., Leprince, J., Chartrel, N., Vaudry, H., Marco, J., et al. (2007). 26RFa, a novel orexigenic neuropeptide, inhibits insulin secretion in the rat pancreas. Peptides 28, 725-730. doi: 10.1016/j.peptides.2006.04.004

Fukusumi, S., Yoshida, H., Fujii, R., Maruyama, M., Komatsu, H., Habata, Y., et al. (2003). A new peptidic ligand and its receptor regulating adrenal function in rats. J. Biol. Chem. 278, 46387-46395. doi: 10.1074/jbc.M305270200

Galusca, B., Jeandel, L., Germain, N., Alexandre, D., Leprince, J., Anouar, Y., et al. (2012). Plasma levels of the orexigenic neuropeptide 26RFa in two populations with low body weight: constitutional thinness and anorexia nervosa. Influence of bingeing/purging episodes. J. Clin. Endocrinol. Metab. 97, 2012-2018. doi: 10. 1210/jc.2011-3396

Gouardères, C., Mazarguil, H., Mollereau, C., Chartrel, N., Leprince, J., Vaudry, H., et al. (2007). Functional differences between $\mathrm{NPFF}_{1}$ and $\mathrm{NPFF}_{2}$ receptor coupling: high intrinsic activities of RFamide-related peptides on stimulation of $\left[{ }^{35} \mathrm{~S}\right] \mathrm{GTP} \gamma \mathrm{S}$ binding. Neuropharmacol 52, 376-386. doi: 10 . 1016/j.neuropharm.2006.07.034

Granata, R., Settanni, F., Trovato, L., Gallo, D., Gesmundo, I., Nano, R., et al. (2014). RFamide Peptides $43 \mathrm{RFa}$ and $26 \mathrm{RFa}$ both promote survival of pancreatic $\beta$-Cells and human pancreatic islets but exert opposite effects on insulin secretion. Diabetes 63, 2380-2393. doi: 10.2337/db13-1522

Greenwood, H. C., Bloom, S. R., and Murphy, K. G. (2011). Peptides and their potential role in the treatment of diabetes and obesity. Rev. Diabet. Stud. 8, 355-368. doi: 10.1900/RDS.2011.8.355

Jiang, Y., Luo, L., Gustafson, E. L., Yadav, D., Laverty, M., Murgolo, N., et al. (2003). Identification and characterization of a novel RF-amide peptide ligand for orphan G-protein-coupled receptor SP9155. J. Biol. Chem. 278, 27652-27657. doi: 10.1074/jbc.M302945200

Kahn, S. E., Cooper, M. E., and Del Prato, S. (2014). Pathophysiology and treatment of type 2 diabetes: perspectives on the past, present, and future. Lancet 383, 1068-1083. doi: 10.1016/S0140-6736(13)62154-6

Kampe, J., Wiedmer, P., Pfluger, P. T., Castaneda, T. R., Burget, L., Mondala, H., et al. (2006). Effect of central administration of QRFP(26) peptide on energy balance and characterization of a second QRFP receptor in rat. Brain Res. 1119, 133-149. doi: 10.1016/j.brainres.2006.08.055

Lectez, B., Jeandel, L., El-Yamani, F. Z., Arthaud, S., Alexandre, D., Mardargent, A., et al. (2009). The orexigenic activity of the hypothalamic neuropeptide $26 \mathrm{RFa}$ is mediated by the neuropeptide $\mathrm{Y}$ and proopiomelanocortin neurons of the arcuate nucleus. Endocrinology 150, 2342-2350. doi: 10.1210/en.2008-1432

Lee, D. K., Nguyen, T., Lynch, K. R., Cheng, R., Vanti, W. B., Arkhitko, O., et al. (2001). Discovery and mapping of ten novel $G$ protein-coupled receptor genes. Gene 275, 83-91. doi: 10.1016/S0378-1119(01)00651-5

Liu, Y., Zhang, Y., Li, S., Huang, W., Liu, X., Lu, D., et al. (2009). Molecular cloning and functional characterization of the first non-mammalian 26RFa/QRFP orthologue in goldfish, Carassius auratus. Mol. Endocrinol. 303, 82-90. doi: 10. 1016/j.mce.2009.01.009

López, M., Seoane, L. M., García Medel, C., Diéguez, C., and Se-arís, R. (2002). Neuropeptide, Y. but not agouti-related peptide or melanin-concentrating hormone, is a target peptide for orexin-A feeding actions in the rat hypothalamus. Neuroendocrinology 75, 34-44. doi: 10.1159/000048219

Moriya, R., Sano, H., Umeda, T., Ito, M., Takahashi, Y., Matsuda, M., et al. (2006). RFamide peptide QRFP43 causes obesity with hyperphagia and reduced thermogenesis in mice. Endocrinology 147, 2916-2922. doi: 10.1210/en.20051580
Mulumba, M., Granata, R., Marleau, S., and Ong, H. (2015). QRFP-43 inhibits lipolysis by preventing ligand-induced complex formation between perilipin A, caveolin-1, the catalytic subunit of protein kinase and hormone-sensitive lipase in 3T3-L1 adipocytes. Biochim. Biophys. Acta 1851, 657-666. doi: 10.1016/j. bbalip.2015.02.005

Mulumba, M., Jossart, C., Granata, R., Gallo, D., Escher, E., Ghigo, E., et al. (2010). GPR103b functions in the peripheral regulation of adipogenesis. Mol. Endocrinol. 24, 1615-1625. doi: 10.1210/me.2010-0010

Organisation Mondiale de la Santé (2016). Rapport Mondial Sur le Diabète. Genève: Organisation Mondiale de la Santé.

Patel, S. R., Murphy, K. G., Thompson, E. L., Patterson, M., Curtis, A. E., Ghatei, M. A., et al. (2008). Pyroglutamylated RFamide peptide 43 stimulates the hypothalamic-pituitary-gonadal axis via gonadotropin-releasing hormone in rats. Endocrinology 149, 4747-4754. doi: 10.1210/en.2007-1562

Prévost, G., Jeandel, L., Arabo, A., Coëffier, M., El Ouahli, M., Picot, M., et al. (2015). The hypothalamic neuropeptide $26 \mathrm{RFa}$ acts as an incretin to regulate glucose homeostasis. Diabetes 64, 2805-2816. doi: 10.2337/db 14-1864

Primeaux, S. D., Blackmon, C., Barnes, M. J., Braymer, D., and Bray, G. A. (2008). Central administration of the RFamide peptides, QRFP-26 and QRFP43, increases high fat food intake in rats. Peptides 29, 1994-2000. doi: 10.1016/ j.peptides.2008.07.024

Sakurai, T., Amemiya, A., Ishii, M., Matsuzaki, I., Chemelli, R. M., Tanaka, H., et al. (1998). Orexins and orexin receptors: a family of hypothalamic neuropeptides and $\mathrm{G}$ protein-coupled receptors that regulate feeding behaviour. Cell 92 , 573-585. doi: 10.1016/S0092-8674(00)80949-6

Schreiber, A. L., Arceneaux, K. P. III, Malbrue, R. A., Mouton, A. J., Chen, C. S., Bench, E. M., et al. (2016). The effects of high fat diet and oestradiol on hypothalamic prepro-QRFP mRNA expression in female rats. Neuropeptides 58, 103-109. doi: 10.1016/j.npep.2016.01.004

Takayasu, S., Sakurai, T., Iwasaki, S., Teranishi, H., Yamanaka, A., Williams, S. C., et al. (2006). A neuropeptide ligand of the G protein-coupled receptor GPR103 regulates feeding, behavioral arousal, and blood pressure in mice. Proc. Natl. Acad. Sci. U.S.A. 103, 7438-7443. doi: 10.1073/pnas.0602371103

Tomer, Y., Dolan, L. M., Kahaly, G., Divers, J., D'Agostino, R. B., Imperatore, G., et al. (2015). Genome wide identification of new genes and pathways in patients with both autoimmune thyroiditis and type 1 diabetes. J. Autoimmun. 60, 32-39. doi: 10.1016/j.jaut.2015.03.006

Ukena, K., Tachibana, T., Iwakoshi-Ukena, E., Saito, Y., Minakata, H., Kawaguchi, R., et al. (2010). Identification, localization, and function of a novel hypothalamic neuropeptide, 26RFa, and its cognate receptor, G protein-coupled receptor-103. Endocrinology 151, 2255-2264. doi: 10.1210/en. 2009-1478

Yamanaka, A., Kunii, K., Nambu, T., Tsujino, N., Sakai, A., Matsuzaki, I., et al. (2000). Orexin-induced food intake involves neuropeptide Y pathway. Brain Res. 859, 404-409. doi: 10.1016/S0006-8993(00)02043-6

Zagorácz, O., Kovács, A., László, K., Ollmann, T., Péczely, L., and Lénárd, L. (2015). Effect of direct QRFP-26 administration into the medial hypothalamic area on food intake in rats. Brain Res. Bull. 118, 58-64. doi: 10.1016/j.brainresbull.2015. 09.004

Conflict of Interest Statement: The authors declare that the research was conducted in the absence of any commercial or financial relationships that could be construed as a potential conflict of interest.

The reviewer VT declared a shared affiliation, though no other collaboration, with several of the authors [NC; MP; ME; HB; DA; YA; GP] to the handling Editor, who ensured that the process nevertheless met the standards of a fair and objective review.

Copyright (c) 2016 Chartrel, Picot, El Medhi, Arabo, Berrahmoune, Alexandre, Maucotel, Anouar and Prévost. This is an open-access article distributed under the terms of the Creative Commons Attribution License (CC BY). The use, distribution or reproduction in other forums is permitted, provided the original author $(s)$ or licensor are credited and that the original publication in this journal is cited, in accordance with accepted academic practice. No use, distribution or reproduction is permitted which does not comply with these terms. 